\title{
COUNTERVAILING 'MISSIONARY' FORCES: EMPIRE AND CHURCH IN ACTS ${ }^{1}$
}

Stellenbosch University

\begin{abstract}
Scholarly consensus has long held that Acts was intended as some sort of Christian apology to the ruling authorities, serving to allay the fears of the imperial forces and their collaborators that the followers of Jesus posed no political threat. This scholarly edifice has been eroded somewhat, among others by the position that the source and direction of the apology were the reverse of the consensus position - a promotion of the imperial regime among followers of Jesus. Given these and other understandings of the imperial setting portrayed in Acts, the relationship between Acts and Empire clearly remains an unfinished and important discussion. Such interpretative positions regarding the relationship between Acts and Empire are briefly reviewed amidst first-century conceptions and positions of power, before highlighting a number of instances in Acts where this relationship comes to a head, suggesting also four possible avenues for further investigation.
\end{abstract}

Key Words: Roman Empire, Jews; Politics, Economics, Kingdom of God

\section{Introduction: How to describe Acts’ Position towards Empire?}

The Acts of the Apostles in the New Testament is a complex book, with multiple dimensions underwritten by specific geographical and historical settings. Often seen as part of a double work ${ }^{2}$ with Luke's Gospel, it tells the continuing story of Jesus migrating into the story of the church, ${ }^{3}$ while seeking to persuade the emerging church about the reach of the gospel and role of Jesus Christ (cf. Bryan 2005:95-105; Walton 2008:74). ${ }^{4}$ The multiple

Shortened, edited version of a paper read at 'Missionary church in Acts' conference in Stellenbosch, 18-20 May 2009.

2 Without denying the dissenting voices, the long-held consensus that Lk and Ac are two parts of a double work provides the backdrop to this paper. Also, postponing the question whether the Empire is portrayed in the same way in the Gospel according to Lk and Ac, it bears mentioning that feminist scholars have argued that while women in Lk occur in gendered pairs that actively participate in the ministry of Jesus, exhibit ideal virtues of leadership, are custodians of the word and bear witness throughout, in Ac women are silenced although the boundaries of the church are continuously pushed beyond the family-like audience of Jesus to the public sphere of the world of men. Women are increasingly marginalised in Ac, and forced to take up ascetic positions in order to retain some memory of their more active role in the beginnings of the movement (Seim 2004).

3 'Church' is used as a useful, collective shorthand to describe the multiple communities of Jesus followers in the middle to late first century CE, often diverse in nature and in various other aspects, and as described by Ac - its use here does not assume a unitary, normative ecclesial structure either in Ac or during the first century CE. However, as indicated by the two instances where the term 'Christian' is used (Ac 11:26; 26:28), the document does seem to be interested in accounting for at least certain aspects of the incipient early Christianity (cf. Taylor 1994:75-94) although the Jesus-follower communities were still deemed a sect or 'reform' movement within the Judaism of the time (cf. Spencer 2005:113 n28).

4 For a brief account of a few important shifts in the history of the interpretation of Ac, cf. Walton (2008:74-76) who stressed the earliest commentary of Chrysostom wanting to relate Ac to Christian life and faith in his day; 
levels and dimensions in Acts complicate its interpretation, and require nuanced investigations - also in accounting for its stance on socio-political matters generally and portrayal of the current imperial context specifically.

Luke-Acts is politically attuned more than most other writings in the New Testament. Already in the Gospel, and to an extent unlike the other gospel authors, Luke was keen to situate the story of Jesus in the political context and circumstances of first century Judea, referring to local and centralised power in the forms of Herod, king of Judea (Lk 1:5), Pontius Pilate, governor of Judea (Lk 3:1-2) and Caesar Augustus (Lk 2:1-2). Luke subtly reminded his readers of Rome's imperial presence in the region, from which the Herodians, a Judaised Idumean dynasty benefitted greatly; references to the census and Roman governor of Syria would have invoked, respectively, notions of power exerted through taxation and a threatening military presence on Judean borders (Burrus 2007:134; cf. Cassidy 1978).

Moreover, Luke and Acts are often regarded as the most pro-Roman Empire documents in the New Testament (Alexander 1991:15), showing Roman authority generally in a positive light (Hollingshead 1998:xii). A long-standing consensus on the book of Acts has described its stance towards Empire along the lines of accommodation: Acts was a deliberate attempt to present the communities of Jesus followers as not constituting a political threat to imperial power and politics. Some scholars have argued that Acts was intent on gaining recognition for the new religious grouping in order to ensure its status as religio licita with its accompanying benefits and privileges (Walton 2004:248). The accommodationist consensus has recently been challenged by a variety of alternative positions, with as the most conspicuous alternative interpretation the suggestion that, rather than an apologetic of the church offered to Empire, the author had the reverse in mind: an apology for the Empire to the followers of Jesus ${ }^{5}$ (Walaskay 1983; cf. Walton 2004:248). ${ }^{6}$

The common element in these broad but diverging heuristic frameworks is their recognition of the significance of Empire in Acts, which allows them to engage the document in full awareness of its complexities. These views set the scene for other

how Ac, courtesy of the 19th missionary movement, increasingly turned into a charter document for Christian mission; how historical critical studies, and redaction criticism in particular, with a decided history of religions focus gradually gave way to debates about the 'delay of the parousia'-debates in work on the double volume by Luke (prefigured in Conzelmann's three-fold understanding of the unfolding history of the church in Lk-Ac - Heilsgeschichte - as replacing the early church expectation of an imminent end: time before Jesus' birth; Jesus' ministry; and, the time of the church [Lk 16:16]); and, how narrative criticism with its focus on the final form of the text, grew into prominence since the 1980s.

5 Arguing against the consensus position, but with little substance, it has been claimed that among others the title 'Lord' (кúpı๐) used for Jesus would not have elicited conflict with Caesar's similar claim; and, in absence of the characteristically strong attacks on the Roman Empire as found in other Second Temple Jewish writings (e.g. 4 Ezra; Sibylline Oracles; Revelation), Luke merely placed the development of the early Christian church within imperial history (Lk 2:1-5; 3:10-14) (Walton 2004:248-249).

6 Besides seeing Lk-Ac as a political apology on behalf of the church (directed at Roman officials) or apology on behalf of Empire addressed at the church, other, in-between options are listed in Walton (2001:2-12): providing legitimation for the church's identity; equipping the churches to live in the Roman Empire; and, that Luke-Acts was not interested in politics at all. Bryan (2005:95) adds also that two other possibilities were advanced in the past, namely that Luke had no interest in Empire at all but within a purely theological focus was intent on showing how God's actions in Jesus Christ were integral to God's faithfulness to his promises to Israel (cf. e.g. LT Johnson, J Jervell); or, that Luke's intention was to prepare his audience for their impending suffering for their faith, either from the Empire or elsewhere (cf. e.g. Cassidy). None of the political explanations are, however, to deny that Lk-Ac portrays a struggle among 'messianic Jews' as part of a broader spectrum of disputes between different Jewish groups about whom or what constituted 'true Israel', the sins that required repentance and the accommodation and role of gentiles in God's salvation and judgement (Tiede 1988:328). 
positions having keen eyes for the ambivalence towards Empire in Luke-Acts, as interventionist literature addressing the intersection of Christian and imperial concerns. While some scholars (e.g. Esler 1987) are of the opinion that Luke-Acts offered legitimation ${ }^{7}$ for the faith of the early followers of Jesus, or for the Christian faith's compatibility with loyalty to the Empire, others (e.g. Cassidy 1987) argue that Acts harboured ambiguous positions towards Empire. ${ }^{8}$ Therefore, a differentiated, threefold purpose has been posited in Acts' attitude towards Empire: communicating the author's faith in Jesus; offering guidance to fellow believers on life under Roman rule; and, providing direction and support for believers who may end up in a trial before Roman authorities (Cassidy 1987). In fact, some argue that Acts presented some scripted scenarios of imperial attitudes towards the followers of Jesus, presenting believers with guidance on how to act in similar situations (cf. Walton 2004:248-249).

The above, brief sampling of an underlying array of positions accounting for the church-Empire relationship in Acts cannot be dissolved into a common consensus - this is also not the ultimate purpose of my argument. Rather, given the pervasive presence of Empire in Acts, most of which is couched in ambivalence, the focus here is on Acts' representation of the Empire, and in particular on Empire and church as countervailing missionary forces. ${ }^{9}$ Firstly, some aspects of power as they appear in Acts in relation to the church and Empire connection are considered, referring to a few instances in the document. Secondly, and more as a probing investigation with rather limited engagement and discussion, it marks out those areas of importance that are relevant to the topic, as they have emerged more recently in scholarly discussions.

\section{Social Conventions and Structures of Power}

\section{Politics and Religion: Two Sides of the Same Coin}

If there is any truth in the claim that, "Particularly in the Roman Empire, politics and religion were not only intimately connected, but arguably the same thing”, ${ }^{\text {(Hollingshead }}$

\footnotetext{
More than just pro-church apologetic, Esler contends that Acts also provided legitimation in the sense of a social process for people who belonged to an old order (even Roman soldiers or administrators, e.g. Ac 10:111:18; 13:6-12; 18:7), with accompanying bonds and commitments, but who are now joining a new order and have to have it explained and justified to them. Stressing the Israelite ancestry of the church (Ac 3:13; 5:30; $15: 10 ; 22: 14 ; 26: 6 ; 28: 25)$, establishes the antiquity and thus credibility of faith in Christ (Esler 1987:1-23, 201-219; cf. Bryan 2005:96) - Walton expresses concern about and caution with regard to Esler's mirrorreading approach to identifying Acts' audience (Walton 2004:249). More generally, for Luke's tendency to draw "a veil over most of the discord and disunity which racked much of the early expansion of Christianity", cf. Dunn (1993:7).

8 For example, given the portrayal of Paul's involvement in social disturbances, notwithstanding his cooperation with the authorities, his loyalty to the Empire was dubious at best (e.g. Ac 24:25; 25:10-11; 28:19).

9 Acknowledging that amidst the various interpretative stances on the relationship church and Empire, other significant issues in Acts such as narratological structure and purpose; historicity, historiography and negotiating identity; genre, and relationship to the gospel of Lk; are also important but cannot be addressed due to the limitations of the paper. On the setting of Ac, cf. Bauckham (1995) for a Palestinian, and Gill and Gempf (1994) for a Greco-Roman setting. For a brief debate on how best to deal with introductory matters regarding Lk-Ac, cf. Spencer (2005:104-24) and Wenham (2005:79-103). Cf. especially the helpful remarks of Spencer (2005:118-121) regarding the tenuous link between textual references and historiographical veracity in the $1^{\text {st }}$ century, expressing care not to claim too much for references such as the Claudius' expulsion of the Jews from Rome (Ac 18:2).

10 The notions we label as 'theological' or 'political' and especially the attempts to maintain a distinction between them would not have been understood in the first century CE. "The attempt to suggest a division here between the 'religious' and the 'political' is entirely unhistorical” (Bryan 2005:27).
} 
1998:x), it is the awareness of the relationship between the respective 'missions' of the Roman Empire and communities of early followers of Jesus that forms the appropriate starting point for further investigation. However, and to begin with, this is not to suggest a level playing field on which the many disparate, fledgling, often disjointed communities of Jesus-followers (which are today in rather unsophisticated fashion, easily assimilated under the rubric 'early Christianity'; here even church) came into contact with the generally welloiled, but in any case overwhelming and vast machinery of the Imperium, deployed with its military, social and religious dimensions across the ancient Mediterranean. However, with the intimate connection between politics and religion, the competition between Empire and church for the submission, obedience or loyalty - the pistis - of first-century people, set the scene for a power struggle; even if during the time of the New Testament it was a muted affair given the size and shape of early Jesus-follower communities in contrast with that of the Empire.

One aspect of this tussle between the Roman Empire and accompanying religious formations practices and the early Jesus follower communities, was that whereas the practices of the latter relied upon a body of beliefs as well as practices and even some sacred texts, in the case of religion as it manifested in and through Empire the focus was predominantly on participation in rituals. "The ritual was what mattered, rather than any doctrinal or theological rationale” (Bryan 2005:117), which would require caution for a construct such as 'Roman imperial theology' (as used by Crossan and Reed 2004:10), even if its constructedness should be admitted. The important point is that officially sanctioned ritual activities constituted religion in the eyes of the Romans; notwithstanding some 'theological reflection' (e.g. Cicero's On the nature of the gods), religious rites were that which constituted reality for the general populace. ${ }^{11}$

This lends further support to the notion that first-century religion and politics were interwoven, both in the sense that the political power and position were appropriated as divinely sourced and maintained, as well as that what the divine contribution required in return, was honour and respect through religious worship of one kind or another. Indeed, not only were those unwilling to participate (i e sacrifice) in Roman religions branded as atheists and seen as a threat to security, but it is also noteworthy that periods of Christian persecution coincided neatly with Empire's troubled times. ${ }^{12}$ Imperial decline was put before the door of those unwilling to participate in the religions sanctified by Empire; and therefore at times the need arose to remove the religious wayward in order to ensure the prosperity of the Empire. Following the relative peace the early church enjoyed, it was later during the times of Decius, Valerian and Diocletian and thus the times of political, military and economical troubles for the Empire, that delivered the most vicious persecutions for the church - until the church eventually persuaded the Roman emperors that this new religion, rather than the gods, were religio and not superstitio ${ }^{13}$ (Bryan 2005:118-119).

11 A notion underwritten by the frequent references to the unacceptable practices (primarily, of not showing deference to Roman gods) rather than improper belief, reasoning or philosophy: "So, for pious Romans, Christians who refused to sacrifice were evidently atheoi - atheists" (Bryan 2005:118).

12 The unwillingness of Christians to participate in Roman sacrifices, constituted largely by the various forms and formats of the imperial cult, meant that they were a threat to the complex and fragile balance of power that existed between the gods and the state (Heyman 2007). The non-participation of Jesus-followers in these sacrifices, when e.g. processions passed by their homes, publicly exposed them (cf. Fiensy 2004:53).

13 Two examples show that the church was nevertheless until the end of the Roman Empire hard-pressed in this regard, and that Roman religion remained a force that kept on challenging Christianity: one, the erstwhile convert and later apostate emperor Julian (361-363 CE); and two, Augustine's protest in City of God that the fall of Rome to Alaric the Visigoth in 410 was not because Rome had forsaken its gods (Bryan 2005:118-119). 


\section{Proselytising: Doing mission/Making Followers?}

The Roman Empire did not proselytise, not even, evidence seems to suggest, in the everwidening reach of the Emperor cult, and considering the scope of the early communities of Jesus followers, it is difficult, on the one hand, to argue for imperial designs specifically aimed at eliminating Jesus-follower missionary activity. The historical situation does not suggest that the imperial cult was a deliberate, full-scale programme intent on the annihilation of Jesus-follower communities. However, from a more structural perspective and acknowledging the vast imperial apparatus including social, political, economical and religious systems and elements - both obvious and harsh such as the military, as well as subtle and apparently innocuous such as a social system like patronage - it is on the other hand not difficult to understand why early followers of Jesus would have experienced imperial designs and activities as potent exertions of power and dominance.

In this regard the emperor or ruler cult remains a significant - but certainly not the only! - means through which the Roman Empire socially engineered itself. All indications are that the emperor cult was of vast significance and of great importance for the Empire, in providing an important centripetal force especially in the outlying areas such as Asia Minor (cf. Friesen 2001). More recently two important aspects relevant to our discussion have emerged: ${ }^{14}$ one is that the emperor cult was not a monolithic construct and the singular term could mistakenly be interpreted to imply either strong direct control exerted in this regard from Rome, or a normativity, in the form of a fixed body of rituals and actions. The second important aspect to be noted about the imperial cult is the extent to which it was absorbed into local religions, influencing and elaborating existing practices to the extent that imperial ideology is privileged without obliterating the particular religious expressions and formations.

Where the Roman Empire and church, or early communities of Jesus followers intersected, it is possible to refer to countervailing missionary forces. Of course, this does not imply understanding Empire as a religious movement, with a programme of proselytising whether for the Empire or the cult. It does argue for a broader understanding of mission in the first century. While a single term for mission ${ }^{15}$ is absent from the New Testament (Swartley 2003:77; cf. Köstenberger 2008:10), the term 'missionary'16 (forces) mostly refers to activities such as evangelism and church planting in a concerted if not always structured

14 Elaborating on work done by Friesen, Thompson and Price on the role and impact of the ruler cult in Asia Minor, Fiensy (2004:48-50) reasons that amidst some remaining uncertainties, the following three conclusions are important: emperor worship was important throughout many levels of society; it had wide support; and, it was more popular in the provinces than in Rome. Fiensy (2004:43-45) also concluded that the word 'asiarch'

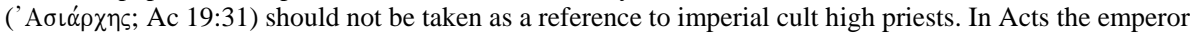
cult is never mentioned directly or dealt with overtly (cf. e.g. Rowe 2005:282).

15 Mission can be understood as a comprehensive term, related to a faith community's perception of its identity and role also as it relates to the world, proclaiming its beliefs and through social engagement. Schnabel's definition (quoted in Blomberg 2007:63) is comprehensive but may reflect a more contemporary approach: "the activity of a community of faith that distinguishes itself from its environment in terms of both the religious belief (theology) and social behaviour (ethics), that is convinced of the truth claims of its faith, and that actively works to win other people to the content of faith and to the way of life of whose truth and necessity the members of that community is convinced". Formulated in this way, it is already evident that the 'missionary' activity of the Roman Empire can be described analogously in view of its proselytising secular (e.g. through offering Roman citizenship) and religious (e.g. the Emperor cult) activities.

16 In contrast, another cognate term missional, can be taken to refer to how the early followers of Jesus identified and eventually organised themselves - in communities and towards others - socially, morally and otherwise. In the NT missional can be related to the self-understanding and sense of identity of the early followers of Jesus, both in terms of self-identity and group-formation, with regard to and sometimes in contrast with the contemporary broader society (cf. Punt 2009). 
way (cf. Punt 2009:185-204) - but it can also mean much more. Therefore, 'missionary' might not be wholly inappropriate to refer to the strong imperial design of conquering all, not only in body but also in mind and soul. After all, the Roman Empire constantly engaged in comprehensive (i e directed at the 'whole world'), and active (i e through military, sociocultural and religious campaigns, strategies and discourse) campaigns to win over people, not simply to subjugate them, although this may have been the dominant experience of the imperial subjects.

At times, the countervailing missionary forces came into clear view in Acts. ${ }^{17}$ The followers of Jesus were accused of acting against imperial interests, words put into the

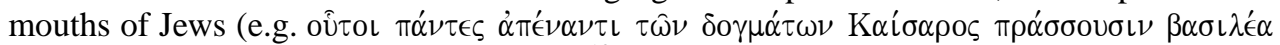

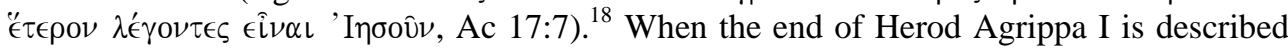
in Ac 12, he is portrayed as putting on his royal attire, and taking his seat on the throne, but

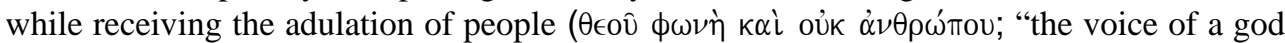
and a man”, Ac 12:22) he met his death. Ac 12:23 insists that Herod was struck dead for not giving glory to God; the next verse reads: "But the word of God grew ( $\eta \tilde{u} \xi \alpha \nu \in \nu$ ) and multiplied ( $€ \pi \lambda \eta \theta \dot{v} \in \tau 0)$ " (Ac 22:24). Notwithstanding the strong efforts by Herod as imperial representative and functionary, it is the power of God in the form of his word that prevailed. At times God's power is mediated through other people in Acts, still bent on overcoming the Roman imperial influence, or through other means. Episodes that can be included under this category would range from the well-known accounts of the miraculous deliverance of Peter from jail with the help of angelic figures (Ac 12:6-11) to mustering the forces of nature such as the earthquake that led to Paul and Silas' 'release' from jail and the conversion of the jailor in Philippi (Ac 16:26).

The apparent good relations between those of the Empire and those of the Kingdom of God in Acts, especially in episodes where the Jews are presented as the cause and instigators of trouble and upheaval (e.g. Ac 21:28-36; 22:22; 23:12-15; 24:1-9), shows cracks, however, as soon as more than the interpretation of the Jewish law is concerned. When Paul is summoned to meet with Felix and his Jewish wife Druscilla, to talk about Christ, it is reported that when Paul mentioned 'justice, self-control and future judgement'

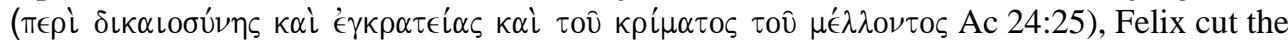
interview short and sent him back to jail - where he was left for two years because Felix did the Jews a favour ( $\left(\theta^{\prime} \lambda \omega \nu \tau \epsilon \chi \alpha \alpha^{\prime} \rho \tau \alpha \kappa \alpha \tau \alpha \theta^{\prime} \epsilon \sigma \theta \alpha \iota\right.$; Ac 24:27), until Festus ${ }^{19}$ took over the reigns from Felix (Ac 24:27; 25:1).

Amidst what can be described an ideological battle, its ambivalence is best seen in Acts 26, with Paul's presentation to king Herod Agrippa II, and his sister Bernice, governor Festus, and some high ranking military staff and other prominent people of the city (Ac 25:23). Telling his life story, Paul focussed on his earlier persecution of the followers of Jesus and his eventual turn to Christ. Agrippa's response was that Paul's learning has made

17 At least on one occasion, in Ac 14:8-18, Paul and Barnabas found themselves also viewed as gods "in the

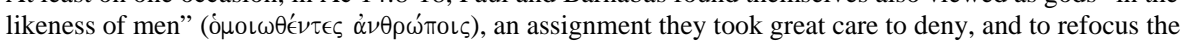
audience's eyes on the "living God who has made the and the earth and the sea and all that is in them", invoking Ex 20:11 (Ac 14:15-17). Cf. also the people on the island Malta who thought of Paul as a god since he was not adversely affected by a snakebite (Ac 28:6).

18 Or the accusations in e.g. Ac 16:19 about following unlawful customs and practices; or in 18:13-15 about acting contrary to the law; according to Ac 18:15 Gallio was quick to debunk the Jews' accusation that Paul

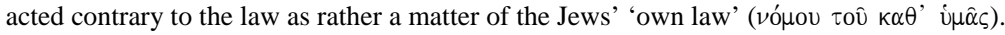

19 And, of course, even in a speech directed at Festus, Acts put Paul on record for claiming that he (Paul) has not

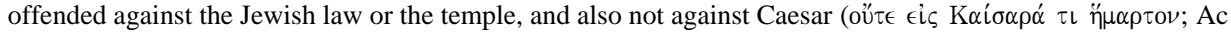
25:8). 


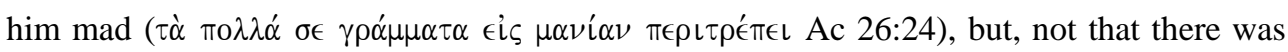
guilt in Paul with regard to the Empire and imperial laws and regulations. Acts has Festus saying explicitly that Paul deserved neither imprisonment nor death; in fact, but for his appeal to Caesar, Paul should have been set free (Ac 26:31-32). While the representatives of Empire in their assessment of the charges against him (Ac 21:28, preaching against, defiling the temple), exonerated Paul regarding the Empire, they nevertheless incarcerated him, according to Acts, to keep the Jews appeased, as a strategy intended to lessen the chances of a revolt.

\section{Engaging Empire in Acts $^{20}$}

It is this uneven setting of different yet competing claims and aspirations between church and Empire that created the breeding ground for the ambiguities that characterised the relationship as presented in Acts. ${ }^{21}$ The point is rather that the book of Acts shows upon the imperial context as the prevailing and primary, socio-political milieu for understanding Jesus in the contemporary urban ${ }^{22}$ world, regardless of whether Empire is derived or inscribed by the text. There are many different angles to the relationship between the kingdom of God and the Roman Empire, to their perception as countervailing forces from different perspectives portrayed in the narrative - with many ambiguities which the Acts narrative was apparently in no hurry to resolve. To such considerations we now turn.

However, first the following three broad, often contradictory but never fully absent or transcended lines should be pointed out - noting that these are certainly not exhaustive of the tendencies which constitute the complexity of the narrative of Acts. They are, however, illustrative and important for recognising the ambivalences pertaining to socio-cultural influences, found in the narrative of Acts. In the first place, there are no indications in Acts that the traditions of Israel are ignored or made superfluous in Acts. In fact, in Acts there is a concerted effort to link the early followers of Jesus with the traditions of Israel and with Israelite ancestors in particular, as is evident in Ac 3:13; 5:30; 15:10; 22:14; 26:6; and 28:25 (already signalled in Lk 1). But then, secondly, and without suggesting contradiction of the former, Acts at the same time stressed the compatibility of faith in Christ with loyalty to the Roman Empire (Esler 1987:201-219; cf. Walton 2004:249). And thirdly and at still another level of discernment, the narrative of apparent accommodation of Jesus followers to imperial designs and structures such as the patronage system (Ac 12;16;18), using the legal system (Ac 21-26), and even befriending Roman officials or garnering the support of urban elite (e.g. Ac 13:12; 17:4), shows a subtle political subversion constantly at work, even in those episodes where the imperial system is ostensibly tolerated if not also affirmed (cf. Burrus 2007:134-144).

20 The role of Empire in Acts should, of course, be understood in conjunction with the broader message of the document. A brief catalogue of five proposals for the centre of Acts from a theological perspective illustrates both diversity but also the equalising force of a strongly theological interpretation: salvation, with God as the prominent driver within the narrative; God, portrayed as purposeful (fulfilling OT promises), as a missionary God focussing on first Jews then also Gentiles, as a God acting through people, and as a saving God; the believing community, complete with positive and negative aspects; Jesus, particularly the message about him; the Holy Spirit, in whom God is personally encountered, accompanied by discussions about the Spirit's role in human empowerment and the Spirit's place in conversion (Walton 2008:76-79).

21 This is not to suggest the elimination of Israel's history and traditions as socio-cultural interpretative framework for understanding Jesus' significance. To use Wenham’s anachronistic terms, the “Jewish/Old Testament rootedness of Jesus and the Christian gospel” is evident in Acts (Wenham 2005:92).

22 The narrative of Acts develops within an urban environment, suggested already by the interesting statistic that half of the references to 'city' in the NT are found in Lk-Ac (cf. Rohrbaugh 1991:125). 
However, the mostly futile attempts to resolve the strains and tensions in Acts, as if it requires statistical calculations for support for or denigration of the Empire, suggest an alternative, constructive approach. In fact, it is in the tensions and strains of the text (Burrus 2007:133-155) that it gradually emerges that two prevailing forces are locked in an intense struggle. Acts shows how totalising claims of one empire (Roman) are opposed with those of another (God's kingdom). The subversiveness of the text comes to full bloom in "the very ambivalence that earned Luke his reputation as an apologist for Rome” (Burrus 2007:139): using the claims and the norms of the Roman Empire against it, the public transcripts in hegemonic situations against the powerful (Scott 1990:106), the value of truth and the importance of justice are affirmed (Ac 21-26). At the same time, however, the imperial system is subverted in constantly portraying the Roman governors as well as the client rulers in a negative light, as was already the case with Herod in Lk 23 (Burrus 2007:140). ${ }^{23}$

\section{Paul's position vis-à-vis Empire}

In Acts the portrayal of Paul's relationship to Empire and the powers that be is, to say the least, ambiguous. ${ }^{24}$ On the one hand, Paul is pictured as holding the coveted Roman citizenship (Ac 16:37; 22:25-29) ${ }^{25}$ and being from Tarsus (Ac 21:39; 22:3) - in addition to his Pharisaic training and life (Ac 22:3; 23:6; 26:5). On the other hand, Paul is often presented as a revolutionary, falling foul of the law, challenging the Roman authorities and frequently landing up in political hot water (cf. Hollingshead 1998:xii).

But the picture remains ambiguous. On the one hand, in Acts 17:6, antagonists accused Paul of belonging to the group that turns the world upside down. "As that Christianity exists within and at the sufferance of the Roman Empire, Acts cannot afford to be too clear about Paul's anarchy” (Walsh 2005:27). On the other hand, from time to time, Paul's innocence is attested in Acts by having him declared innocent in local courts of law (e.g. Acts 25:8). In the end, however, Paul's and the broader message of Acts built upon the resurrection which 'apocalyptically undoes the world', posed a challenge for the status quo at different levels. "For Paul, grace is a disruptive miracle. Such miracles do not merely transform chaos into order. First, they transform someone else's world into chaos" (Walsh 2005:27) - and in Acts it is the Roman Empire in its different formats that are often at the receiving end.

Again, while Paul is portrayed as being at odds with imperial forces ${ }^{26}$ it was the Roman imperial system which also protected Paul, at least in providing due legal process. Not a stranger to political trouble, the accusation that Paul initiated a riot in Ephesus led to his running away from the town (Ac 19:23-20:1) whereas his involvement in creating a public

23 A first area replete with tension is the role ascribed to Jews amidst the countervailing missionary forces of church and Empire - however, space does not allow further discussion here. Another area which had to be omitted here because of space constraints, concerns socio-economic matters; although on economical terrain also, the forces of Empire and church pulled in different directions, "Luke's view of economic relations finally presents an even more mixed message than does his view of Roman politics” (Burrus 2007:144).

24 For a brief survey of the portrait of Paul in Acts, cf. Walton (2004:242-244). The question whether this portrayal is matched with how Paul appears in his letters cannot be addressed here; and therefore also not whether Ac reflects the interpretation of Paul by a later generation/tradition?

25 In both instances, in political situations where Paul found himself respectively appearing before a Roman proconsul and in the custody of a Roman centurion. For more on Paul in prison, cf. Rapske (1994).

26 Literally challenging the authorities against all odds, such as in Philippi where he insisted that the magistrates do not send the police but they should come themselves and set Paul and Silas free, Ac16:37. Cf. Burrus (2007:150-152) on Ac 16 and the contrasting images found in Lydia and the spirit-possessed slave girl in Philippi. 
disturbance in Philippi landed him in jail (Ac 16:16-40). He is portrayed as acquainted with and well-versed in the legal system, so when appearing in Roman courts of law, he apparently defended himself with eloquence (Ac 24-25). Paul apparently also knew to appeal to Caesar in order to avoid a trial by the Jewish leaders which might have led to his summary execution (Ac 25:10-11).

Paul's ambiguous attitude ${ }^{27}$ towards and even relationship with the Empire is probably best seen in the tension between his appeal to Caesar on the one hand, and his insistence on the lordship of Christ on the other hand. In Acts, Paul is certainly not alone in his affirmation of Christ as Lord, as kúpıos, a title imbued by power and set in politics. Already in the first chapter of Acts, Jesus is addressed likewise (Ac 1:6), soon confirmed by his ascension $^{28}$ and the proclamation of the 'two men in white robes' (Ac 1:9-11), and dramatically in Peter's Pentecost speech (cf. Ac 2:36ff). In affirming the lordship of Jesus, it appears from Acts that it was for Paul about more than the use of a title, kúpıos for Jesus Christ. In Ac 17, it is Paul and Silas who are dragged from the synagogue in Thessalonica, accused of proclaiming a different 'king' (Ac 17:7). ${ }^{29}$

In the end, the portrayal of Paul's subversion of Empire in Acts was not of matching emperor and Empire blow by blow, but his conceptualising of the socio-political significance of Jesus Christ, described in terms resonating with power structures which the Roman Empire would probably have chosen to reserve for their own use. Paul's position remained ambiguous, at once availing him of privileges he evidently found himself entitled to as Roman, yet also insisting on the Lordship of Christ

\section{Kingdom of God}

Related to Paul's affirmation of Jesus as Lord, is the notion of the Kingdom of God. It would be a mistake to consider the 'political' stance of Acts only in relation to its reference to politically or ideologically loaded terminology, but it would be an equally serious mistake not to consider such expressions. An obvious term demanding some investigation

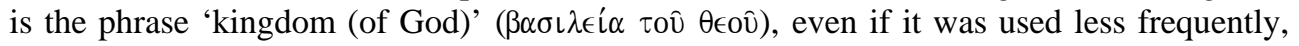
almost 10 times, in Acts (Ac 1:3; 1:6; 4:26; 8:12; 14:22; 19:8; 20:25; 28:23; 28:31) compared to the almost 50 times in Luke's gospel. Kingdom-terminology soon appears in Acts, with the first words of Jesus' disciples being about the restoration of the kingdom to

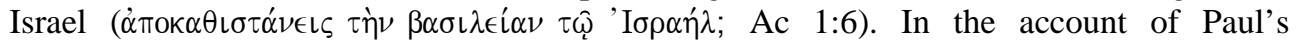
preaching ministry, the arguments between Paul and Jews in the synagogue in Ephesus which is reported to have continued for 3 months, was about the 'kingdom of God' (Ac 19:8). Later, in Paul's pre-Jerusalem visit speech to elders in Ephesians, Paul also emphasised that he preached the 'kingdom of God' (Ac 20:25). ${ }^{30}$

27 "Whatever we think of the historicity of Acts, the portrait of Paul before the authorities both pagan and Jewish tells us a good deal about the way in which the Jewish traditions were being reanimated and retrieved. He is prepared to submit to the courts, but is also more than prepared to remind them of their business and to call them to account when they overstep their duty. He uses his own Roman citizenship when it suits the demands of this mission. But at the same time he is fearless in announcing, and living by, a different allegiance” (Wright 2005:70).

28 Roman emperors often used the notion of the ascension of their predecessors' souls to heaven as final proof of the latter's divinity (Wright 2005:64).

29 In this regard, Ac 17:22-31, the well-known Areopagus speech, is also important for Paul's emphasis on the creator God who calls all people to him, and who will judge the world in righteousness 'by a man appointed

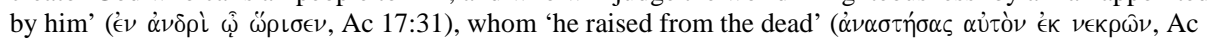
17:31).

${ }^{30}$ The term 'kingdom (of God)' is also not a hugely popular term in Paul's letters (used only 8 times, Rm 14:17; 
While comparatively the 'imperial kingdom' remains on the background in Acts, the imperial context requires investigation of Kingdom-thinking in Acts. One scholar contended that the kingdom of David of the Old Testament informs Luke's description of Jesus' kingship and kingdom, and subsequently describes how Luke-Acts evidences a shift from Davidic Christology to Kingdom ecclesiology (Hahn 2005:294-326). In the Old Testament, and amidst frequent references to the kingdom of David, the phrase kingdom of God is not found; however, the Chronicler used the phrase 'kingdom of Yahweh' to describe the Davidic monarchy (1 Chr 28:5; 2 Chr 13:8; cf. 1 Chr 17:14; 29:11-22). ${ }^{31}$ Acts operates with a Davidic kingdom ecclesiology, derived from the Davidic royal Christology of Luke's gospel, ${ }^{32}$ and the '́кк $\lambda \eta \sigma i \alpha$ of Acts is the restored kingdom of David - bearing in mind that the anticipated restoration had the character of transformation rather than reimplementation (Hahn 2005:297-306).

Ac 28 picks up upon and continues the themes sounded in Simeon's oracles in Lk 2:2535. It is especially the notion that Jesus will lead to "the fall and rising of many in Israel" (Lk 2:34) that reappear in its enactment among the Jewish leaders who turned up in 'great numbers' ( $\pi \lambda \in \epsilon^{\prime} 0 \nu \in S$, Ac 28:23) to listen to Paul (cf. Tiede (1988:333-334; cf. Hahn 2005:316). Importantly, in the final few verses of Acts and Paul's presence in Rome, the emphasis is on the ongoing preaching activity of Paul and particularly on its content, the Kingdom of God (Acts 28:23, 31). ${ }^{33}$ Paul is preaching the Kingdom of God in the heart of the Empire, indirectly juxtaposing the former with the latter, confronting the very fibre and make-up of the imperial regime with the message about the one crucified by Roman soldiers who has mediated another Kingdom, soon to be expanded to include also the Roman Empire. Two countervailing missionary forces meet head-on!

\section{Political/military functionaries}

Looking at the roles played by political and military functionaries of the Roman Empire in Acts, the narrative would seem to support the views of scholars who hold that hostility directed against Jesus followers was not due to imperial suspicion or disapproval (e.g. Crossan and Reed 2004:30-32). That is, the church was neither the enemy of Rome nor Rome the enemy of the church - and that 'sensible Roman administrators' and 'sensible Christians' knew this (Bryan 2005:105). However, the insistence that God held authorities, such as the Roman Empire, accountable to fulfil the purpose for which God gave them the power (Bryan 2005), as the authoritative grid for perceiving the socio-political of every New Testament document, places too heavy a secondary interpretative grid on the texts, requiring conformation of all to the same norm and obscuring unique features inherent to each document.

4:20; 1 Cor 6:9, 10; 15:24, 50; Gal 5:21; 1 Th 2:12; cf. the seven times that is used in the deutero-Pauline tradition: Eph 5:5; Col 1:13; 4:11; 2 Th 1:5; 1 Tm 1:17; 2 Tm 4:1; 4:18).

31 Chronicles further makes it clear that the kingdom of David was in the Old Testament context the manifestation of God's rule over the whole world, both Israel and the nations, since the reign of the house of David was understood to be based on a divine covenant in which the son of David was also declared to be son of God (2 Sam 7:14; Ps 2:7; 89:27).

32 Identifying eight characteristics of the Davidic monarchy, all eight are found by Hahn in Luke’s description of Jesus, with its decidedly political nature borne out by three of which have to do with exercising power: rule over the twelve tribes; rule over and international empire; and everlasting rule (Hahn 2005:300-301; 303-306; 315). The link between Davidic Christology and kingdom ecclesiology can be found in the first three narratives in Acts: Ac 1:1-11; 1:12-26; Ac 2.

33 Ac 28:31 is probably confirmation that Jesus' reference to the geographical spread of the gospel (Ac 1:8), which informs the layout of the Acts-narrative, also encapsulates the spread of the Davidic kingdom. Jerusalem was David's city (2 Sam 5:6-10); Judea his tribal land (e.g. 2 Sam 5:5), Samaria northern Israel (e.g. 1 Kgs 12:16), and the ‘ends of the earth’ the Gentiles (e.g. Is 49:6) (cf. Hahn 2005:316). 
On the one hand, it is of course so that in Acts, positive reactions of Roman officials towards the apostles of Christ abound, ranging from a town clerk quelling a labour-related upheaval (Өópußov; Ac 20:1) by the Artemis-traders in Ephesus (Ac 19:35-40), claiming, among others, that Gaius and Aristarchus (Paul's companions) were 'neither sacrilegious

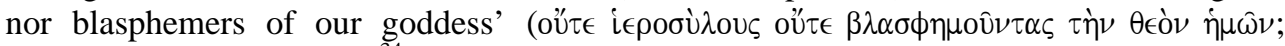
19:37), to governors Felix ${ }^{34}$ and Festus attributing Jewish antipathy towards Paul and his compatriots to intra-Jewish disputes and minor concerns (e.g. Ac 24:22; 25:19). Festus agreed to Paul's appeal to Caesar (Ac 25:9-12), and the centurion of the soldiers escorting Paul on the ship to Rome, decided against killing the prisoners when their ship is lost at sea, because he wanted to spare Paul's life (Ac 27:43). Moreover, Roman functionaries and soldiers were included in conversion stories; the centurion Cornelius's conversion through Peter (Ac 10-12), and the conversion of the pro-consul Sergei Paulus (Cyprus) (Ac 13:12), and the prison guard in Ac 16 are probably among the best known.

On the other hand, however, and firstly, the political and military functionaries of Empire were instrumental in the arrest, incarceration and punishment of the followers of Christ; ${ }^{35}$ secondly, the Jewish vassal kings and other local authorities derived their authority and power from the imperial source, which can hardly lead to a call to vindicate Empire; ${ }^{36}$ and, thirdly, the local elites and religious figures also held their positions largely due to their relationship with Empire (often, that of clients to the Empire as patron). In the end, according to Acts these military and political figures were like other Gentile(s) instruments in God's hands, legitimating a Gentile mission without legitimating Gentile supremacy: "the Gentiles are still understood by Luke to be the means of divine vengeance, but these Gentiles are Israel's enemies - probably the Roman armies, and certainly not the gentile Christians" (Tiede 1988:338). Acts affirms both God's faithfulness, even to a faithless people, and Gods vengeance and vindication (cf. Ac 11:17-18; 13:46-47), which is probably best illustrated in the political and military characters in Acts: the missionary force of God's kingdom overruns the petty postures of the imperial forces.

\section{Confluence of Imperial Power and Local Authorities in Acts (cf. 3.1; 3.4)}

It is not only the Roman authorities that are in view as dominating forces in Acts, as the early Christians are at times portrayed as offering fairly strong resistance to the Jewish authorities in particular, as well. It is also clear from the outset that it is not possible to neatly distinguish between some ostensible Roman political and Jewish religious formation and authorities, given the porous boundaries between imperial power and the authority of the local elite, even if it is the latter's religious involvement that are mostly obvious and pronounced.

Through their 'government without bureaucracy' (Garnsey and Saller 1987:20-40), the Roman Empire yielded administrative authority to indigenous elites which had a twofold

34 Hoping and waiting for a bribe, Felix is said to have often summoned and conversed with Paul (Ac 24:26) whether because of fear of Paul or regarding him a dangerous person, remains unclear in the way Felix's interactions with Paul is reported.

35 The numerous trials in Acts, besides Jesus Christ's trial in Lk 22-23, include those in Acts: 4:3-23 (Peter and others; in Jerusalem); 5:17-40 (Peter and others; in Jerusalem); 6:9-7:60 (Stephan; in Jerusalem); 16:19-36 (Paul and Silas; in Philippi); 17:5-9 (Paul and others; in Thessalonica); 18:12-17 (Paul; in Corinth); 21:2722:30 (Paul; in Jerusalem); 22:30-23:10 (Paul; in Caesarea); 24:1-26 (Paul; in Caesarea); 25:5-12 (Paul; in Caesarea); 25:24-26:32 (Paul; in Caesarea); 28 (Paul; in Rome). Cf. Malina and Neyrey (1991:121).

36 Some of the most violent actions in Acts are ascribed to the Jewish king Herod Agrippa I: that he had James brother of John killed by the sword (12:2); then arrested Peter, during the festival of Unleavened Bread (12:3), and later had two guards killed after an angel reportedly freed Peter from prison (12:19). 
purpose. On the one hand the local elites played the important role of keeping the imperial wheels turning, in many ways including that they ensured the collection of tribute, organising business and politics, garnering support for Empire through bestowing benevolence and public works programmes. On the other hand, the elites were an important aspect of the imperial divide and rule-politics (Moore 2006:199; cf. Chow 2000 on patronage), since popular resentment and even uprisings could be blamed on them while the imperial powers retained ultimate authority by remaining remote and unavailable.

In this regard, one of the most prominent depictions of an early Christian challenge to Jewish authorities is found in the narrative of Stephan (Ac 6:8-7:70). In the narrative, Stephan, appearing before the Sanhedrin, was ultimately stoned for his refusal to recant from his reported insistence that Jesus will break down the temple and destroy the morals of Moses (Ac 6:14), and for his counter-conventional interpretation of Israelite (Jewish) history, concluding that their betraying and killing Jesus was true to form within his portrayal of the killing of God's prophets in the Jewish tradition (Ac 7:52). It is also significant to note that the Stephan narrative follows shortly after the well-known exclamation by Peter to the Sanhedrin about being obedient to God rather than to people (Ac 5:29).

\section{Conclusion}

Considering empire is not an activity best allocated to the study of antiquity. The presence of imperial forces of various kinds in today's 21st century world is palpable, ranging from a global superpower such as the United States of America not unwilling to unleash its considerable military power against those perceived to threaten USA interests, to the excessively powerful multinational corporations with their geo-political footprint and ability to manipulate and control the lives of billions, not to mention their environmental impact and back home, in the form of both the imperialism of political, economic, socio-cultural and religious forces, as well as the confluence of these forces as illustrated around the time of (and subsequent to) the April 2009 general election. Accounting for empire, for its roots and reach, for its influence and impact, remains important as much as it is complex.

The hybridical situations in which the church formations described in Acts found themselves in relation to Roman imperial forces, requires of modern day readers to disentangle these countervailing missionary forces. This does not mean a simplistic resolving of the ambiguities of Luke's ideological stance into claimed certainties and clarities, since while it on the one hand exhibits an apologetic, accommodating strategy, it on the other hand expressed subtle, even craftily phrased, critique towards imperial tendencies - attention is required for Acts' political subversiveness. ${ }^{37}$ It is the ongoing struggle between the countervailing missionary forces of the Empire of Rome and the Kingdom of God in Acts that remains when the document draws to a close. But, while locked in ideological positions, the final verse makes the subversive element of Acts clear:

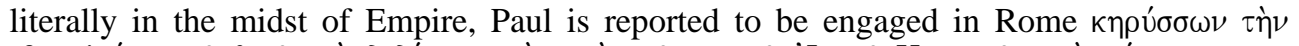

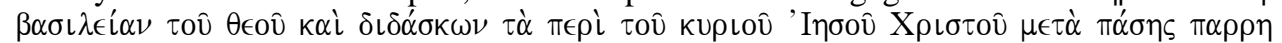

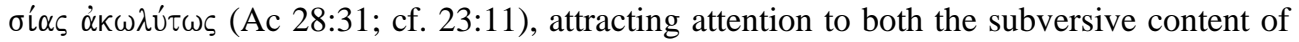
Paul's preaching and his challenging style.

37 "For Luke, more than almost any other biblical writer (the most obvious exception being the author of Revelation), is attuned to the political complexity and universalizing ambitions of a Roman Empire that perhaps bears even more resemblance than do colonialist regimes of modern Europe to the globalizing, postmodern 'neo-empire' of the twenty-first century” (Burrus 2007:152). 
It is with the consideration of imperialist hegemony and ambivalence that a final underlying question should be asked: is the response to Acts' presentation of countervailing missionary forces of Empire and church in the end simply a matter of choice, or also of reconceptualising? In other words, and given the tainted histories of both Empire and church - not to mention the time when the two became one! - does studying Acts and discerning missionary patterns not involve more than the mere choice between the hegemonic tentacles of a Roman Empire, or the overpowering proselytising of the church? In other words, and presuming a favourable reception among us for the church, is another step not also required? Is reconceptualising not also on the cards, that is, a different way of conceptualising the power and reign of God, over the whole world and its entire people?

\section{BIBLIOGRAPHY}

Alexander, L 1991. Introduction. In Images of Empire, (ed.) L Alexander, 11-8. JSOT Supplementum Series, vol. 112. Sheffield: JSOT.

Bauckham, R (ed.) 1995. The Book of Acts in Its Palestinian Setting. Book of Acts in Its First Century Setting, vol. 4. Grand Rapids: Eerdmans.

Bryan, C 2005. Render to Caesar. Jesus, the Early Church and the Roman Superpower. Oxford: Oxford University Press.

Blomberg, CL 2007. Mission in the Bible. Non-Existent in the Old Testament but Ubiquitous in the New? Themelios 32(2): 62-74.

Burrus, V 2007. The Gospel of Luke and the Acts of the Apostles. In A Postcolonial Commentary on the New Testament Writings, (eds.) FF Segovia, and RS Sugirtharajah, 133-55. The Bible and Postcolonialism, vol. 13. New York: T\&T Clark.

Cassidy, RJ 1978. Jesus, Politics, and Society: A Study of Luke's Gospel. Maryknoll: Orbis.

Cassidy, RJ 1987. Jesus and Politics in the Acts of the Apostles. Maryknoll: Orbis.

Cassidy, RJ 2001. Christians and Roman Rule in the New Testament: New Perspectives. New York: Crossroad.

Crossan, JD, and JL Reed 2004. In Search of Paul. How Jesus's Apostle Opposed Rome's Empire with God's Kingdom. A New Vision of Paul's Words and World. New York: Harper, SanFrancisco.

Dunn, JDG 1993. The Epistle to the Galatians. Black’s New Testament Commentaries. Peabody: Hendrickson.

Esler, PF 1987. Community and Gospel in Luke-Acts: The Social and Political Motivations of Lucan Theology. SNTSMS, vol. 57. Cambridge: Cambridge University Press.

Fiensy, D 2004. The Roman Empire and Asia Minor. In The Face of New Testament Studies. A Survey of Recent Research, (eds.) S McKnight, and GR Osborne, 36-56. Grand Rapids: Baker Academic.

Friesen, SJ 2001. Imperial Cults and the Apocalypse of John. Reading Revelation in the Ruins. Oxford: Oxford University Press.

Garnsey, P and R Saller 1987. The Roman Empire. Economy, Society and Culture. London: Duckworth.

Gilbert, G 2006. Luke-Acts and Negotiation of Authority and Identity in the Roman World. In The Multivalence of Biblical Texts and Theological Meanings, (ed.) C Helmer 
(with the assistance of Charlene T Higbe), 83-104. Symposium Series, vol. 37. Atlanta, Leiden: SBL, Brill.

Gill, DWJ, and C Gempf, (ed.) 1994. The Book of Acts in Its Greco-Roman Setting. Book of Acts in Its First Century Setting, vol. 2. Grand Rapids: Eerdmans.

Hahn, S 2005. Kingdom and Church in Luke-Acts: From Davidic Christology to Kingdom Ecclesiology. In Reading Luke. Interpretation, Reflection, Formation, (eds.) C Bartholomew, JB Green, and AC Thiselton, 294-326. Scripture and Hermeneutics Series, vol. 6. Grand Rapids: Paternoster; Zondervan.

Heyman, G 2007. The Power of Sacrifice: Roman and Christian Discourses in Conflict. Washington: Catholic University of America Press.

Hollingshead, JR 1998. The Household of Caesar and the Body of Christ. A Political Interpretation of the Letters from Paul. Lanham: University Press of America.

Howell, JR 2008. The Imperial Authority and Benefaction of Centurions and Acts 10:34-43: A Response to C Kavin Rowe. Journal for the Study of the New Testament 31(1): 25-51. DOI: 10.1177/0142064X08095177.

Jervell, J 1972. Luke and the People of God. Minneapolis: Augsburg.

Köstenberger, AJ. “The Place of Mission in New Testament Theology: An Attempt to Determine the Significance of Mission within the Scope of the New Testament's Message as a Whole.” 2008 [cited 28 January 2008]. Available from http://www.biblicalfoundations.org/pdf/NT\%20Theology\%20and\%20Mission.PDF

Malina, BJ, and JH Neyrey 1991. Conflict in Luke-Acts: Labelling and Deviance Theory. In The Social World of Luke-Acts. Models for Interpretation, (ed.) J Neyrey, 97-122. Peabody: Hendrickson.

Moore, SD 2006b. Mark and Empire: 'Zealot' and 'Postcolonial' Readings. In The Postcolonial Biblical Reader, (ed.) RS Sugirtharajah, 193-205. London: Blackwell.

Neyrey, JH 1991. The Symbolic Universe of Luke-Acts: "They Turn the World Upside Down”. In The Social World of Luke-Acts. Models for Interpretation, (ed.) J Neyrey, 271-304. Peabody: Hendrickson.

Neyrey, JH, (ed.) 1991. The Social World of Luke-Acts: Models for Interpretation. Peabody: Hendrickson Publishers.

Oakes, P 2002. Rome in the Bible and the Early Church. Carlisle; Grand Rapids: Paternoster; Baker Academic.

O’Toole, RF 1983. Luke’s Position on Politics and Society in Luke-Acts. In Political Issues in Luke-Acts, 1-17. Maryknoll: Orbis.

Punt, J 2009. The letter to the Galatians. In Missionary Perspectives in the New Testament. Pictures from chosen New Testament literature, (eds.) Du Plessis, J, E Orsmond and $\mathrm{H}$ van Deventer, 185-204. Wellington: BybelMedia.

Rapske, B 1994. The Book of Acts and Paul in Roman Custody. Book of Acts in Its First Century Setting, vol. 3. Grand Rapids: Eerdmans.

Robbins, VK 1991. Luke-Acts: A Mixed Population Seeks a Home in the Roman Empire. In Images of Empire, (ed.) L Alexander, 202-21. JSOT Supplement Series, vol. 112. Sheffield: JSOT.

Rohrbaugh, RL 1991. The Pre-Industrial City in Luke-Acts: Urban Social Relations. In The Social World of Luke-Acts. Models for Interpretation, (ed.) J Neyrey, 125-49. Peabody: Hendrickson. 
Rowe, CK 2005. Luke-Acts and the Imperial Cult: A Way through the Conundrum? Journal for the Study of the New Testament 27(2): 279-300.

Sanders, JT 1987. The Jews in Luke-Acts. London: SCM.

Seim, TK 2004. Double Message: Patterns of Gender in Luke-Acts. London: T\&TClark International.

Spencer, FS 2005. Preparing the Way of the Lord: Introducing and Interpreting Luke's Narrative: A Response to David Wenham. In Reading Luke. Interpretation, Reflection, Formation, (eds.) C Bartholomew, JB Green, and AC Thiselton, 104-24. Scripture and Hermeneutics Series, vol. 6. Grand Rapids: Paternoster; Zondervan.

Swartley, WM 2003. Bosch and Beyond: Biblical Issues in Mission. Mission Focus: Annual Review 11 (2003 Supplement): 77-105.

Talbert, JH 1983. Martyrdom in Luke-Acts and the Lucan Social Ethic. In Political Issues in Luke-Acts, (eds.) RJ Cassidy, and PJ Scharper, 106-9. Maryknoll: Orbis.

Taylor, J 1994. Why were the Disciples First Called "Christians” At Antioch? (Acts 11,26). Revue Biblique 101(1): 75-94.

Tiede, DL 1988. "Glory to Thy People, Israel”: Luke-Acts and the Jews. In The Social World of Formative Christianity and Judaism. Essays in Tribute to Howard Clark Kee, (eds.) J Neusner, P Borgen, ES Frerichs, and R Horsley, 327-41. Philadelphia: Fortress Press.

Walaskay, PW 1983. “And So We Came to Rome”: The Political Perspective of St Luke. SNTSMS, vol. 49. Cambridge: Cambridge University Press.

Walsh, R 2005. Finding St Paul in Film. New York \& London: T\&TClark.

Walton, S 2002. The State They Were in: Luke's View of the Roman Empire. In Rome in the Bible and the Early Church, (ed.) P Oakes, 1-41. Carlisle; Grand Rapids: Paternoster; Baker Academic.

Walton, S 2004. Acts. Many Questions, Many Answers. In The Face of New Testament Studies. A Survey of Recent Research, (eds.) S McKnight, and GR Osborne, 229-50. Grand Rapids: Baker Academic.

Walton, S 2008. Acts. In Theological Interpretation of the New Testament. A Book-by-Book Survery, (eds.) KJ Vanhoozer, DJ Treiter, and NT Wright, 74-83. Grand Rapids: SPCK/Baker Academic.

Wenham, D 2005. The Purpose of Luke-Acts: Israel's Story in the Context of the Roman Empire. In Reading Luke. Interpretation, Reflection, Formation, (eds.) C Bartholomew, JB Green, and AC Thiselton, 79-103. Scripture and Hermeneutics Series, vol. 6. Grand Rapids: Paternoster; Zondervan. 